\title{
Exergetic Optimization of a Solar Photovoltaic Array
}

\author{
Faramarz Sarhaddi, Said Farahat, Hossein Ajam, and Amin Behzadmehr \\ Department of Mechanical Engineering, Shahid Nikbakht Faculty of Engineering, University of Sistan \& Baluchestan, \\ Zahedan 98164-161, Iran \\ Correspondence should be addressed to Faramarz Sarhaddi, fsarhaddi@eng.usb.ac.ir
}

Received 5 June 2009; Revised 20 September 2009; Accepted 6 November 2009

Recommended by Marc A. Rosen

\begin{abstract}
An exergetic optimization is developed to determine the optimal performance and design parameters of a solar photovoltaic (PV) array. A detailed energy and exergy analysis is carried out to evaluate the electrical performance, exergy destruction components, and exergy efficiency of a typical PV array. The exergy efficiency of a PV array obtained in this paper is a function of climatic, operating, and design parameters such as ambient temperature, solar radiation intensity, PV array temperature, overall heat loss coefficient, open-circuit voltage, short-circuit current, maximum power point voltage, maximum power point current, and PV array area. A computer simulation program is also developed to estimate the electrical and operating parameters of a PV array. The results of numerical simulation are in good agreement with the experimental measurements noted in the previous literature. Finally, exergetic optimization has been carried out under given climatic, operating, and design parameters. The optimized values of the PV array temperature, the PV array area, and the maximum exergy efficiency have been found. Parametric studies have been also carried out.
\end{abstract}

Copyright ( $) 2009$ Faramarz Sarhaddi et al. This is an open access article distributed under the Creative Commons Attribution License, which permits unrestricted use, distribution, and reproduction in any medium, provided the original work is properly cited.

\section{Introduction}

Renewable energies are going to be a main substitute for fossil fuels in the coming years for their clean and renewable nature. A solar photovoltaic (PV) array is one of the most significant and rapidly developing renewable-energy technologies, and its potential future uses are notable.

$\mathrm{PV}$ array is a semiconductor device, which converts light energy directly into useful electricity. The energy payback time (EPBT) of a PV system lies between 10 and 15 years depending on insulation and the performance of it. If the performance of a PV array can be increased, the energy payback time can be reduced. Therefore, the optimized performance evaluation of a PV array is important.

PV array performance parametrically depends on climatic, operating, and design parameters such as ambient temperature, solar radiation intensity, PV array temperature, overall heat loss coefficient, open-circuit voltage, shortcircuit current, maximum power point voltage, maximum power point current, and PV array area. It can be evaluated in terms of energy efficiency and exergy efficiency. Its evaluation based on the first and second laws of thermodynamics is known as energy efficiency and exergy efficiency, respectively.

The energy analysis has some deficiencies $[1,2]$; fundamentally, the energy concept is not sensitive with respect to the assumed direction of the process; for example, energy analysis does not object if heat is considered to be transferred spontaneously in the direction of increasing temperature. It also does not distinguish the quality of energy; for example, $1 \mathrm{~W}$ of heat equals $1 \mathrm{~W}$ of work or electricity. Energy analyses on their own incorrectly interpret some processes $[1,2]$; for example, environmental air, when isothermally compressed, maintains its energy (e.g., enthalpy) equal to zero, whereas the exergy of the compressed air is greater than zero. However, exergy data are more practical and realistic in comparison with the respective energy values. Thus, exergy analysis usually provides a more realistic view of process than energy analysis; some times, they are different $[1,2]$.

The energy conversion factor of a solar PV system sometimes is described as efficiency, but this usage sometimes leads to some difficulties such as follows [3]. The energy 
efficiency of a PV array can be considered as the ratio of the electricity generated to the total, or global, solar irradiation. In this definition, only the electricity generated by a PV array is considered. The other components and properties of a PV array, such as ambient temperature, PV array, temperature, chemical potential components, and heat capacity of a PV array, are not directly taken into account [3]. However, the exergy efficiency of a PV array includes most of the climatic, geometric, and operating parameters of a PV array and involves the thermal properties and chemical potential components of it directly [3].

A little work has been carried out in field of PV array exergy analysis or exergetic optimization of it.

Ross and Hsiao [4] investigated some theoretical thermodynamic limits of photochemical solar energy conversion efficiency.

Landsberg and Markvart [5] studied the Carnot factor in PV cell theory and obtained an expression for opencircuit voltage, which is equal to the band-gap multiplied by the Carnot efficiency. Markvart and Landsberg [6] also discussed the thermodynamics and reciprocity of solar energy conversion by considering PV, photochemistry, and photosynthesis phenomena.

Würfel [7] studied thermodynamic limitations of solar energy conversion, based on an entropy concept, and calculated the upper efficiency as 0.86 for maximally concentrated solar radiation.

Smestad [8] examined the concepts of hot carrier and light converter, indicating that electrons are ejected not only as heat but also as light.

Bisquert et al. [9] presented some physical and chemical principles of PV conversion and found the relation between chemical potential and open-circuit voltage of PV cell to be dependent on Carnot and statistical factors.

Gong and Kulkarni [10] considered the optimization process of a grid connected PV system. They optimized array size and the tilt angle of array surface based on energy analysis.

Cernivec et al. [11] optimized the optical and electrical performance of a CIGS solar cell from a perspective based on band-gap engineering. They examined structures with different CIGS absorber thicknesses and bulk and/or hetero-interface recombination lifetimes and discussed their optimized parameters in the light of experimental achievements.

Ghoneim [12] developed a computer simulation program in order to determine the thermal performance of a photovoltaic powered water pumping system in the Kuwait climate. He found the optimum values of PV array size, PV array orientation, and pump-motor-hydraulic system characteristics.

Badescu [13] studied the effect of latitude and climate on PV module shape based on energy analysis. He obtained the optimized value of PV cells number in series and strings number for various climatic conditions.

Sahin et al. [3] carried out the thermodynamic analysis of a PV array based on chemical potential components. They also obtained exergy components and PV array exergy efficiency. Finally, they compared energy, electrical, exergy efficiencies under given climatic and operating conditions. However, they did not fulfill the computer simulation and optimization of a PV array.

Skoplaki et al. [14] suggested a simple semiempirical correlation for PV array temperature. They investigated the effect of solar irradiance, ambient temperature, and wind speed on PV array temperature. However, they ignored free convection and radiation losses from PV array to the environment.

Abdolzadeh and Ameri [15] investigated the possibility of improving the performance of a photovoltaic water pumping system by spraying water over the front of PV array experimentally. They pointed out that the efficiency of PV array can be increased due to spraying water over the front of PV array.

Joshi et al. [16] developed a thermal model for the PV module integrated with solar air collector and validated it experimentally. They indicated that PV module temperature can be controlled and reduced in consequence of changing the mass flow rate of air in solar collector and the efficiency of PV module can be increased.

Joshi et al. [17] also studied the performance characteristics of a photovoltaic (PV) and photovoltaic-thermal $(\mathrm{PV} / T)$ system in terms of energy efficiency and exergy efficiency, respectively. They proposed equations for the energy, electrical, and exegry efficiency of a PV system. Finally, they calculated the energy, electrical, and exegry efficiencies under given experimental data and gave useful results. However, they did not obtain the exergy destruction components of PV array. They also did not carry out the numerical simulation and optimization of $\mathrm{PV}$ array.

Sarhaddi, Farahat and Ajam investigated exergetic optimization of solar collector systems [18-20].

In this paper, a detailed energy and exergy analysis will be carried out to evaluate the electrical performance, exergy destruction components, and exergy efficiency of PV array. An equation for PV array exergy efficiency will be derived based on exergy destruction. A computer simulation program will be developed to predict the electrical and operating parameters of PV array. Finally, the exergetic optimization of PV array will be carried out; also, the effect of climatic, design, and operating parameters on exergy efficiency will be studied.

PV array exergy analysis is parametrically dependent on its energy analysis. Hence, firstly PV array energy analysis will be carried out. Then the exergy destruction components and exergy efficiency of PV array will be computed and optimized.

\section{Energy Analysis}

The proof of governing equations on PV array energy analysis is not included in order to have a brief note.

A PV array is nonlinear device and can be represented by its current-voltage $(I-V)$ characteristic curve. There are several mathematical models, which can describe $I-V$ characteristic curve [21]. Five-parameter photovoltaic model 
(Figure 1) for $I-V$ characteristic curve is defined as [21]

$$
I=I_{L}-I_{o}\left[\exp \left(\frac{V+I R_{s}}{a}\right)-1\right]-\frac{\left(V+I R_{s}\right)}{R_{\mathrm{sh}}},
$$

where $I$ and $V$ represent current and voltage at load, and $a, I_{L}, I_{o}, R_{s}$, and $R_{\mathrm{sh}}$ are ideality factor, light current, diode reverse saturation current, series resistance, and shunt resistance, respectively.

The second terms on the right-hand side of (1) indicate diode current $\left(I_{D}\right)$. In order to calculate five reference parameters $\left(a_{\mathrm{ref}}, I_{L, \text { ref }}, I_{o, \text { ref }}, R_{s, \text { ref }}\right.$, and $\left.R_{\mathrm{sh}, \text { ref }}\right)$, five pieces of information are needed at reference conditions [21]. These five pieces of information are defined as follows [21].

At short circuit current:

$$
I=I_{\text {sc,ref }}, \quad V=0 .
$$

At open circuit voltage:

$$
I=0, \quad V=V_{\text {oc, ref. }} .
$$

At the maximum power point:

$$
I=I_{\mathrm{mp}, \mathrm{ref}}, \quad V=V_{\mathrm{mp}, \mathrm{ref}} .
$$

At the maximum power point:

$$
\left[\frac{d(I V)}{d V}\right]_{\mathrm{mp}}=0 .
$$

At short circuit:

$$
\left[\frac{d I}{d V}\right]_{\mathrm{sc}}=-\frac{1}{R_{\mathrm{sh}, \mathrm{ref}}} .
$$

Reference conditions or standard rated conditions (SRCs) are defined as follows [22].

The solar cell temperature at reference conditions is

$$
T_{\text {cell, ref }}=25^{\circ} \mathrm{C} \text {. }
$$

The solar radiation intensity at reference conditions is

$$
G_{\text {ref }}=1000 \mathrm{~W} / \mathrm{m}^{2} .
$$

Substituting the above five pieces of information into (1), the following equations are obtained:

$$
\begin{gathered}
I_{\mathrm{sc}, \text { ref }}=I_{L, \text { ref }}-I_{o, \text { ref }}\left[\exp \left(\frac{I_{\mathrm{sc}, \text { ref }} R_{s, \text { ref }}}{a_{\text {ref }}}\right)-1\right]-\frac{I_{\mathrm{sc}, \text { ref }} R_{s, \text { ref }}}{R_{\mathrm{sh}, \text { ref }}}, \\
0=I_{L, \text { ref }}-I_{o, \text { ref }}\left[\exp \left(\frac{V_{\mathrm{oc}, \text { ref }}}{a_{\mathrm{ref}}}\right)-1\right]-\frac{V_{\mathrm{oc}, \text { ref }}}{R_{\mathrm{sh}, \text { ref }}}, \\
I_{\mathrm{mp}, \text { ref }}=I_{L, \text { ref }}-I_{o, \text { ref }}\left[\exp \left(\frac{V_{\mathrm{mp}, \text { ref }}+I_{\mathrm{mp}, \text { ref }} R_{\mathrm{s}, \text { ref }}}{a_{\mathrm{ref}}}\right)-1\right] \\
-\frac{\left(V_{\mathrm{mp}, \text { ref }}+I_{\mathrm{mp}, \text { ref }} R_{\mathrm{s}, \text { ref }}\right)}{R_{\mathrm{sh}, \text { ref }}}
\end{gathered}
$$

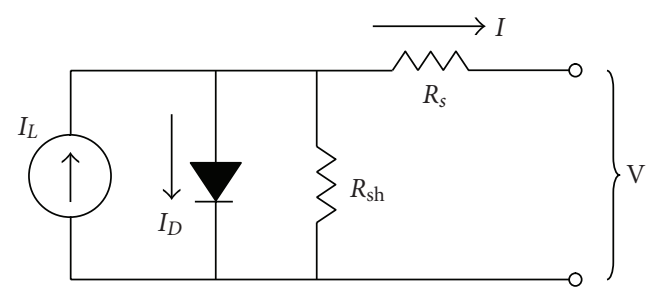

FIGURE 1: Equivalent electrical circuit in the five-parameter photovoltaic model [21].

$$
\begin{gathered}
{\left[\frac{d(I V)}{d V}\right]_{\mathrm{mp}}=0,} \\
{\left[\frac{d I}{d V}\right]_{\mathrm{sc}}=\frac{-1}{R_{\mathrm{sh}, \mathrm{ref}}},}
\end{gathered}
$$

where $V_{\mathrm{oc}}, V_{\mathrm{mp}}, I_{\mathrm{sc}}$, and $I_{\mathrm{mp}}$ are open-circuit voltage, maximum power point voltage, short-circuit current, and maximum power point current, respectively. The subscript "ref" indicates the value of parameters at the reference conditions.

Equations (9)-(13) are a set of nonlinear equations that can be solved with numerical methods. Solving (9)-(13) gives the value of five parameters $\left(a_{\mathrm{ref}}, I_{L, \text { ref }}, I_{o, \text { ref }}, R_{s, \text { ref }}\right.$, and $\left.R_{\text {sh,ref }}\right)$, at the reference conditions $\left(T_{\text {cell, ref }}=25^{\circ} \mathrm{C}, G_{\text {ref }}=\right.$ $1000 \mathrm{~W} / \mathrm{m}^{2}$ ). In order to calculate the model parameters at new climatic and operating conditions $\left(G_{\text {new }}, T_{\text {cell,new }}\right)$, a set of translation equations is used as follows [14, 21, 23]:

$$
\begin{aligned}
T_{\text {cell }}= & \left(T_{\mathrm{amb}}+\left(\frac{G}{G_{\mathrm{ref}}}\right)\left(\frac{U_{L, \mathrm{NOCT}}}{U_{L}}\right)\left(T_{\text {cell, NOCT }}-T_{\mathrm{amb}, \mathrm{NOCT}}\right)\right. \\
& \left.\times\left[1-\frac{\eta_{\mathrm{el}, \mathrm{ref}}}{(\tau \alpha)}\left(1+\gamma_{\mathrm{ref}} T_{\text {cell, }, \mathrm{ref}}\right)\right]\right) / \\
& \left(1-\frac{\gamma_{\mathrm{ref}} \eta_{\mathrm{el}, \mathrm{ref}}}{(\tau \alpha)}\left(\frac{G}{G_{\text {ref }}}\right)\left(\frac{U_{L, \mathrm{NOCT}}}{U_{L}}\right)\right. \\
& \left.\times\left(T_{\text {cell, NOCT }}-T_{\mathrm{amb}, \mathrm{NOCT}}\right)\right)
\end{aligned}
$$

$$
\begin{gathered}
\frac{a}{a_{\text {ref }}}=\frac{T_{\text {cell }}}{T_{\text {cell,ref }}}, \\
\frac{I_{\mathrm{o}}}{I_{\mathrm{o}, \text { ref }}}=\left(\frac{T_{\text {cell }}}{T_{\text {cell, ref }}}\right)^{3} \exp \left(\frac{\varepsilon N_{c}}{a_{\text {ref }}}\left(1-\frac{T_{\text {cell,ref }}}{T_{\text {cell }}}\right)\right), \\
I_{L}=\left(\frac{G}{G_{\text {ref }}}\right)\left[I_{L, \text { ref }}+\alpha\left(T_{\text {cell }}-T_{\text {cell, ref }}\right)\right], \\
\Delta T=T_{\text {cell }}-T_{\text {cell,ref }}, \\
\Delta I=\alpha\left(\frac{G}{G_{\text {ref }}}\right) \Delta T+\left(\frac{G}{G_{\text {ref }}}-1\right) I_{\text {sc,ref }}, \\
\Delta V=\beta \Delta T-R_{s} \Delta I, \\
I_{\text {new }}=I_{\text {ref }}+\Delta I, \\
V_{\text {new }}=V_{\text {ref }}+\Delta V,
\end{gathered}
$$

where $T_{\text {cell }}, T_{\text {cell,ref }}, T_{\text {cell,NOCT }}, T_{\text {amb }}, T_{\text {amb,NOCT }}, G$, and $G_{\text {ref }}$ are solar cell temperature, solar cell temperature at the reference 
conditions, nominal operating cell temperature, ambient temperature, ambient temperature at NOCT conditions, solar radiation intensity, and solar radiation intensity at the reference conditions, respectively. Further, parameters $U_{L}$, $U_{L, \mathrm{NOCT}}, \eta_{\mathrm{el}, \mathrm{ref}},(\tau \alpha), \varepsilon, N_{c}, \alpha, \beta$, and $\gamma_{\text {ref }}$ are overall heat loss coefficient, overall heat loss coefficient at NOCT conditions, electrical efficiency at the reference conditions, the effective product of transmittance-absorptance, semiconductor band gap energy (1.12 eV for silicon solar cell), cells number in series, current temperature coefficient, voltage temperature coefficient, and efficiency correction coefficient for temperature $\left(0.004{ }^{\circ} \mathrm{C}^{-1}\right.$ for silicon solar cell $)$, respectively.

PV module manufacturers usually give temperature coefficients and NOCT conditions [22]. The new values of maximum power point voltage and maximum power point current are obtained from solved $I-V$ characteristic curve and (12) simultaneously at new climatic and operating conditions.

In the previous studies [3-17], PV array overall loss coefficient $\left(U_{L}\right)$ has been assumed as a constant factor or a variable with little effect, whereas it is not constant. The overall heat loss coefficient of PV array includes convection and radiation losses:

$$
U_{L}=h_{\text {conv }}+h_{\text {rad }} .
$$

The convective heat transfer coefficient is given by [24]

$$
h_{\text {conv }}=2.8+3 V_{w}
$$

where $V_{w}$ is wind speed. The radiative heat transfer coefficient between PV array and surroundings is obtained from [25]

$$
h_{\text {rad }}=\varepsilon_{g} \sigma\left(T_{\text {sky }}+T_{\text {cell }}\right)\left(T_{\text {sky }}^{2}+T_{\text {cell }}^{2}\right),
$$

where $\varepsilon_{g}$ and $\sigma$ are PV array emissivity and the StefanBoltzmann's constant, respectively, and the effective temperature of the sky $\left(T_{\text {sky }}\right)$ is calculated from the following empirical relation [25]:

$$
T_{\text {sky }}=T_{\text {amb }}-6 .
$$

The energy efficiency of a PV system can be defined as the ratio of the output energy of the system (i.e., electrical energy) to the input energy (i.e., solar energy) received on photovoltaic surface.

The maximum energy efficiency of a PV system is given by $[3,17]$

$$
\eta_{\mathrm{en}}=\frac{V_{\mathrm{oc}} I_{\mathrm{sc}}}{S} .
$$

However, this definition of energy efficiency is restricted to theoretical cases. In (20), S is solar absorbed flux and it is given by

$$
S=G A_{\text {arr }}=G\left(N_{s} N_{m} A_{\text {mod }}\right),
$$

where $A_{a r r}, N_{m}$, and $N_{s}$ are $P V$ array area, number of modules in series per string, and number of strings, respectively. PV module area $\left(A_{\text {mod }}\right)$ is given by

$$
A_{\text {mod }}=L_{1} L_{2},
$$

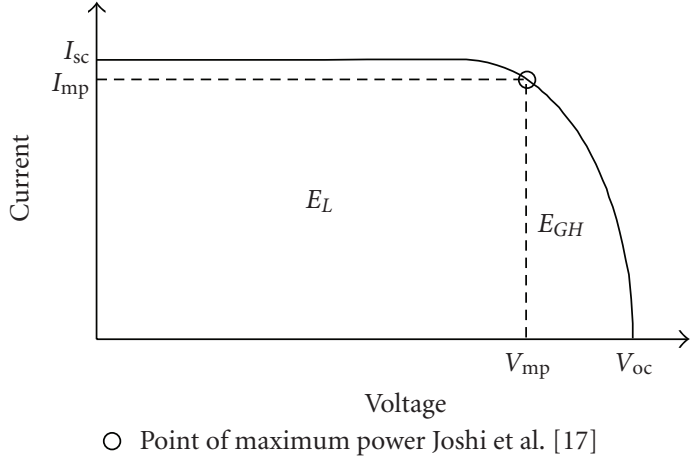

FIGURE 2: Representation of a general current-voltage characteristic curve and its parameters [17].

where $L_{1}$ and $L_{2}$ are the length of solar module and the width of solar module, respectively.

For PV systems in practical cases, energy efficiency measures the ability of converting solar energy into electrical energy $[3,17]$. The electrical power output is the product of voltage and current of photovoltaic device. This conversion efficiency is not constant, even under constant solar irradiation. However, there is a point of maximum power, where voltage is $V_{\mathrm{mp}}$, which is less than open-circuit voltage $\left(V_{\mathrm{oc}}\right)$ but close to it, and current is $I_{\mathrm{mp}}$, which is less than shortcircuit current $\left(I_{s c}\right)$ but close to it (Figure 2). In Figure 2, $E_{G H}$ stands for the highest energy level of electron at maximum solar irradiation conditions.

$E_{G H}$ is equivalent to area under the $I-V$ characteristic curve $\left(\int_{V=0}^{V_{\text {oc }}} I(V) d V\right)$. In addition, $E_{L}$ stands for the lowenergy content of electron, which is the practical case, as shown by the rectangular area in the same figure. $E_{L}$ is thus equivalent to $I_{\mathrm{mp}} V_{\mathrm{mp}}$. The maximum power point is restricted by a term called "fill factor" as

$$
\mathrm{FF}=\frac{V_{\mathrm{mp}} I_{\mathrm{mp}}}{V_{\mathrm{oc}} I_{\mathrm{sc}}} .
$$

The energy efficiency of a PV system at maximum power is defined as the ratio of actual electrical output to input solar energy incident on PV surface area and it is given by $[3,16$, 17]

$$
\eta_{\mathrm{el}}=\frac{V_{\mathrm{mp}} I_{\mathrm{mp}}}{S} .
$$

This efficiency is also called actual electrical efficiency. The electrical efficiency of a PV array can also be defined in terms of fill factor (FF) as follows:

$$
\eta_{\mathrm{el}}=\frac{\mathrm{FF} \times V_{\mathrm{oc}} I_{\mathrm{sc}}}{S} .
$$

\section{Exergy Analysis}

Exergy analysis is a technique that uses the conservation of mass and conservation of energy principles together with the second law of thermodynamics for the analysis, design, and improvement of energy and other systems. Exergy is defined 
as the maximum amount of work that can be produced by a system or a flow of mass or energy as it comes to equilibrium with a reference environment [26]. Exergy efficiency is the ratio of total output exergy to total input exergy [26-29]:

$$
\eta_{\mathrm{ex}}=\frac{\mathrm{Ex}_{\mathrm{out}}}{\mathrm{Ex}_{\mathrm{in}}}=1-\frac{I_{\mathrm{c} \cdot \mathrm{v}}}{\mathrm{Ex}_{\mathrm{in}}},
$$

where $E x_{\text {in }}, E x_{\text {out }}$, and $I_{\text {c.v }}$ are inlet exergy, outlet exergy, and irreversibility in control volume, respectively.

The inlet exergy includes solar radiation intensity exergy. According to the Petela theorem, it is given by $[1,2]$

$$
\mathrm{Ex}_{\mathrm{in}}=S\left(1-\frac{4}{3} \frac{T_{\mathrm{amb}}}{T_{\text {sun }}}+\frac{1}{3}\left(\frac{T_{\mathrm{amb}}}{T_{\text {sun }}}\right)^{4}\right)
$$

where $\mathrm{T}_{\text {sun }}$ is the sun's temperature in Kelvin.

The irreversibility in control volume includes external exergy losses from control volume and internal exergy losses (exergy destructions) in control volume [28-30]:

$$
I_{\mathrm{c} \cdot \mathrm{v}}=\sum\left(\mathrm{Ex}_{\mathrm{los}}+\mathrm{Ex}_{\mathrm{des}}\right) \text {. }
$$

The external exergy losses caused by heat leakage are given by [18-20]

$$
\mathrm{Ex}_{\mathrm{los}}=U_{L} A_{\mathrm{arr}}\left(T_{\text {cell }}-T_{\mathrm{amb}}\right)\left(1-\frac{T_{\mathrm{amb}}}{T_{\text {cell }}}\right) .
$$

The internal exergy losses (exergy destructions) include four terms; one is caused by optical losses in PV array surface $[31,32]$ :

$$
\mathrm{Ex}_{\mathrm{des}, \mathrm{opt}}=S\left(1-\frac{T_{\mathrm{amb}}}{T_{\text {sun }}}\right)(1-(\tau \alpha))
$$

the second term is caused by the temperature difference between PV array surface and the sun temperature [1820, 31, 32]:

$$
\operatorname{Ex}_{\text {des }, \Delta T_{\text {sun }}}=(\tau \alpha) S T_{\text {amb }}\left(\frac{1}{T_{\text {cell }}}-\frac{1}{T_{\text {sun }}}\right) ;
$$

the third term is caused by the temperature variation of PV array with respect to the reference environmental state [1820]:

$$
\operatorname{Ex}_{\text {des }, \Delta T_{\text {arr }}}=\frac{m_{\text {cell }} C_{p} T_{\mathrm{amb}}}{\Delta \mathrm{t}}\left(\ln \left(\frac{T_{\text {cell }}}{T_{\mathrm{amb}}}\right)-\frac{\left(T_{\text {cell }}-T_{\mathrm{amb}}\right)}{T_{\text {cell }}}\right),
$$

where $m_{\text {cell }}$ and $\Delta t$ are PV array mass and time interval, respectively. Time interval is chosen according to the time step of experiment course [3].

The specific heat capacity of silicon solar cell $\left(C_{p}\right)$ is calculated from [33]

$$
C_{p}=0.844+1.18 \times 10^{-4} T_{\text {cell }}-1.55 \times 10^{4} T_{\text {cell }}^{-2} .
$$

The fourth term is electrical exergy destruction [17]:

$$
\mathrm{Ex}_{\mathrm{des}, \mathrm{el}}=\left(I_{\mathrm{sc}} V_{\mathrm{oc}}-I_{\mathrm{mp}} V_{\mathrm{mp}}\right)
$$

The exergy efficiency of PV array: substituting (27)-(34) into (26), the exergy efficiency equation of PV array is obtained:

$$
\begin{aligned}
& \eta_{\mathrm{ex}}=1-\left\{(1-(\tau \alpha))+\frac{U_{L} A_{\mathrm{arr}}\left(T_{\text {cell }}-T_{\mathrm{amb}}\right)\left(1-\frac{T_{\mathrm{amb}}}{T_{\mathrm{cell}}}\right)}{S\left(1-\frac{4}{3} \frac{T_{\mathrm{amb}}}{T_{\text {sun }}}+\frac{1}{3}\left(\frac{T_{\mathrm{amb}}}{T_{\mathrm{sun}}}\right)^{4}\right)}\right. \\
& +\frac{(\tau \alpha) S T_{\mathrm{amb}}\left(\frac{1}{T_{\text {cell }}}-\frac{1}{T_{\text {sun }}}\right)}{S\left(1-\frac{4}{3} \frac{T_{\text {amb }}}{T_{\text {sun }}}+\frac{1}{3}\left(\frac{T_{\text {amb }}}{T_{\text {sun }}}\right)^{4}\right)} \\
& +\frac{\frac{m_{\text {cell }} C_{p} T_{\text {amb }}}{\Delta t}\left(\ln \left(\frac{T_{\text {cell }}}{T_{\text {amb }}}\right)-\frac{\left(T_{\text {cell }}-T_{\text {amb }}\right)}{T_{\text {cell }}}\right)}{S\left(1-\frac{4}{3} \frac{T_{\text {amb }}}{T_{\text {sun }}}+\frac{1}{3}\left(\frac{T_{\text {amb }}}{T_{\text {sun }}}\right)^{4}\right)} \\
& \left.+\frac{\left(I_{\mathrm{sc}} V_{\mathrm{oc}}-I_{\mathrm{mp}} V_{\mathrm{mp}}\right)}{S\left(1-\frac{4}{3} \frac{T_{\mathrm{amb}}}{T_{\mathrm{sun}}}+\frac{1}{3}\left(\frac{T_{\mathrm{amb}}}{T_{\mathrm{sun}}}\right)^{4}\right)}\right\} \text {. }
\end{aligned}
$$

\section{Formulation of Optimization Problem}

The electrical and exergetic models presented in the previous sections have been inserted into a MATLAB computational program. In this program, most of the geometric parameters and operating conditions can be variables. The formulation of optimization problem, considering the quantities $T_{\mathrm{amb}}$, $T_{\text {amb,NOCT }}, T_{\text {cell,ref }}, T_{\text {cell,NOCT }}, T_{\text {sun }}, G, G_{\text {ref }}, \Delta t, \alpha, \beta, \gamma_{\text {ref }}, \eta_{\text {el,ref }}$, $\mathcal{E},(\tau \alpha), L_{1}, L_{2}, A_{\mathrm{mod}}, V_{\mathrm{oc}, \mathrm{ref}}, V_{\mathrm{mp}, \mathrm{ref}}, I_{\mathrm{sc}, \mathrm{ref}}, I_{\mathrm{mp}, \mathrm{ref}}, V_{\mathrm{w}}$, and so forth, as constant parameters is given by

Maximize $\eta_{\mathrm{ex}}=(35)$,

subject to

$(1,9-19)$ and (21),

$300 \leq T_{\text {cell }} \leq 350 \mathrm{~K}$,

$A_{\text {mod }} \leq A_{\text {arr }} \leq 16 A_{\bmod } \mathrm{m}^{2}$,

$m_{\text {cell }}, C_{p}, I_{o}, I_{L}, R_{s}, R_{\mathrm{sh}}, a, I_{\mathrm{sc}}, V_{\mathrm{oc}}, I_{\mathrm{mp}}, V_{\mathrm{mp}}, S, U_{L}$,

$\eta_{\mathrm{en}}, \eta_{\mathrm{el}}, \mathrm{FF} \geq 0$

$N_{s}, N_{m}, N_{c} \geq 1$ and are integer,

where $T_{\text {cell }}$ and $A_{\text {arr }}$ are independent parameters and $m_{\text {cell }}$, $C_{p}, I_{o}, I_{L}, R_{s}, R_{\mathrm{sh}}, a, I_{\mathrm{sc}}, V_{\mathrm{oc}}, I_{\mathrm{mp}}, V_{\mathrm{mp}}, S, U_{L}, \eta_{\mathrm{en}}, \eta_{\mathrm{el}}, F F$, $N_{s}, N_{m}$, and $N_{c}$ are dependent parameters in optimization procedure. Whereas the objective function and its constraints are nonlinear, it has been maximized numerically with MATLAB optimization toolbox. MATLAB uses the variations of sequential quadratic programming (SQP) method for constrained optimization [34].

\section{Results and Discussion}

5.1. Experimental Validation. The experimental results of Barker and Norton [35] for a rack-mounted PV array allow 


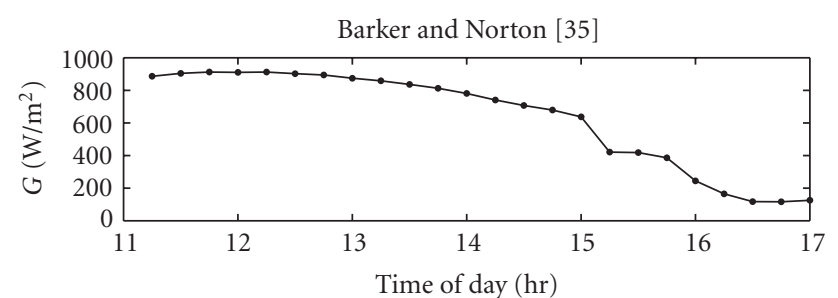

(a)

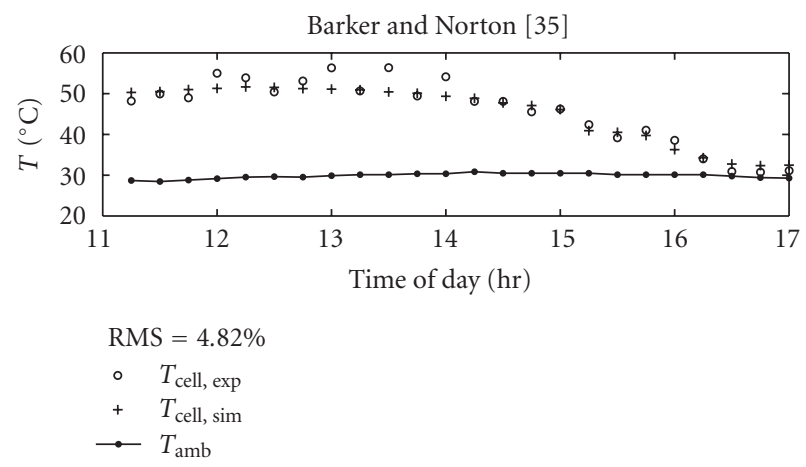

(b)

Figure 3: The variations of solar radiation intensity, ambient temperature, experimental PV array temperature, and simulated PV array temperature during the test day.

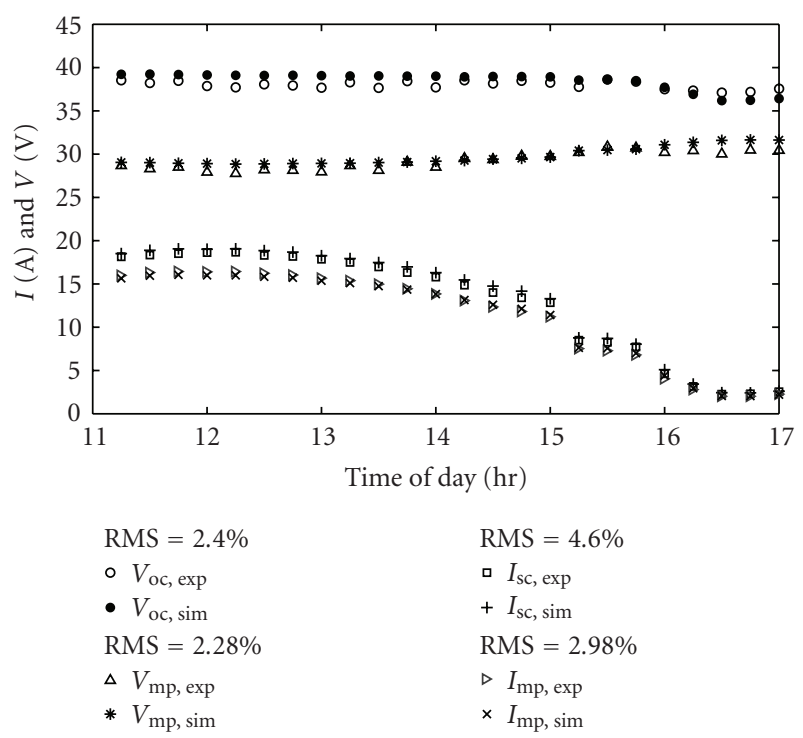

FIgURE 4: The simulated values of open-circuit voltage, maximum power point voltage, short-circuit current, maximum power point current, and the corresponding experimentally measured data during the test day.

the checking of results obtained by computer simulation. The measured data in [35] include the solar radiation intensity, ambient temperature, PV array temperature, opencircuit voltage, maximum power point voltage, short-circuit current, and maximum power point current. Additional information about the experiment method and its conditions

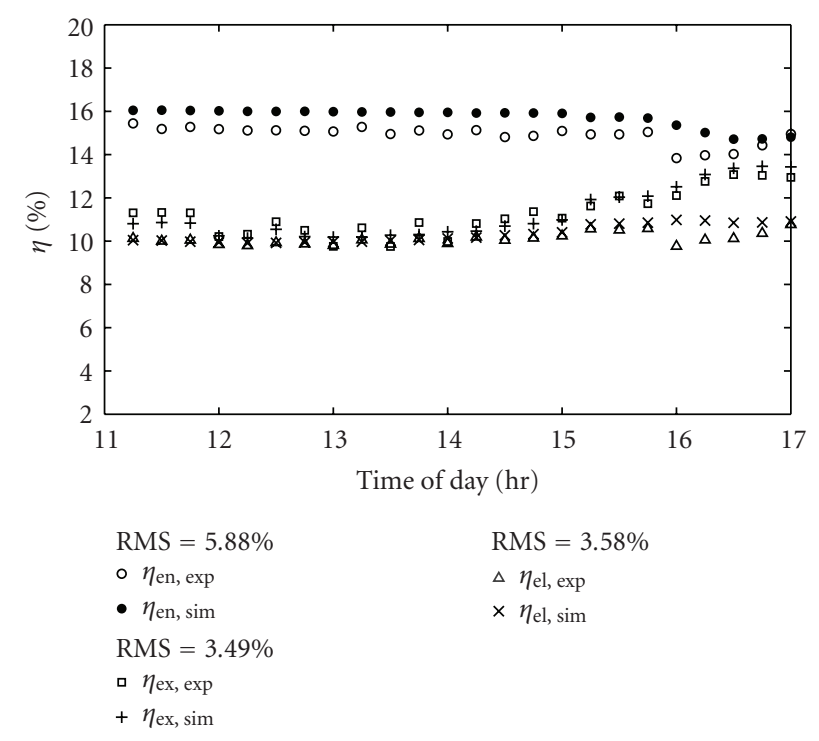

FIGURE 5: The simulated and experimental values of energy efficiency, exergy efficiency, and electrical efficiency during the test day.

is found in [35]. The experimental values of the abovementioned parameters have been obtained from Figure 8 and Figure 9 of [35].

The simulated values of PV array temperature, opencircuit voltage, maximum power point voltage, short-circuit current, and maximum power point current in present work have been validated by their corresponding experimental values in [35].

Climatic, operating, and design parameters of PV array during validation process are described in Table 1. They correspond to the experimental system described by Barker and Norton [35], except that they did not report the wind speed observed over the course of their tests. This affects the convective heat transfer coefficient between PV array surface and the ambient air. In Table 1 , a wind speed of $0.5 \mathrm{~m} / \mathrm{s}$ is assumed to have a comparison with the experimental data.

In order to compare the simulated results with the experimental measurements, a root mean square percentage deviation (RMS) has been evaluated by following equation $[16,21]$ :

$$
\mathrm{RMS}=\sqrt{\frac{\sum\left[100 \times\left(X_{\exp , i}-X_{\mathrm{sim}, i}\right) / X_{\exp , i}\right]^{2}}{n}},
$$

where $\mathrm{n}$ is the number of record of experimental data over the course of experiment.

The variations of solar radiation intensity, ambient temperature, and PV array temperature during the test day are shown in Figure 3. The simulated values of PV array temperature are also shown in the same figure for comparison. It can be seen from this figure that there is a good agreement between the simulated and experimental values of PV array temperature with standard percentage deviation $($ RMS $)=4.82 \%$. 
TABLE 1: Climatic, operating and design parameters of PV array [22, 35].

\begin{tabular}{|c|c|c|}
\hline Solar PV module parameters & Value in validation & Value in optimization \\
\hline PV module type & $\begin{array}{l}\text { Siemens SM55, } \\
\text { monocrystalline silicon }\end{array}$ & $\begin{array}{c}\text { Siemens SM55, } \\
\text { monocrystalline silicon }\end{array}$ \\
\hline Number of modules in series per string, $N_{m}$ & 2 & From optimization \\
\hline Number of strings, $N_{s}$ & 6 & From optimization \\
\hline The solar radiation intensity at the reference conditions, $G_{\text {ref }}$ & $1000 \mathrm{~W} / \mathrm{m}^{2}$ & $1000 \mathrm{~W} / \mathrm{m}^{2}$ \\
\hline The solar radiation intensity, $G$ & From experimental data & $700 \mathrm{~W} / \mathrm{m}^{2}$ \\
\hline The ambient temperature, $T_{\mathrm{amb}}$ & From experimental data & $300 \mathrm{~K}$ \\
\hline The ambient temperature at NOCT conditions, $T_{\mathrm{amb}, \mathrm{NOCT}}$ & $293.15 \mathrm{~K}$ & $293.15 \mathrm{~K}$ \\
\hline The cell temperature at the reference conditions, $T_{\text {cell, ref }}$ & $298.15 \mathrm{~K}$ & $298.15 \mathrm{~K}$ \\
\hline The nominal operating cell temperature, $T_{\text {cell,NOCT }}$ & $318.15 \mathrm{~K}$ & $318.15 \mathrm{~K}$ \\
\hline The PV array temperature, $T_{\text {cell }}$ & $(14)$ & From optimization \\
\hline The sun temperature, $T_{\text {sun }}$ & $5760 \mathrm{~K}$ & $5760 \mathrm{~K}$ \\
\hline Wind speed, $V_{w}$ & $0.5 \mathrm{~m} / \mathrm{s}$ & $0.5 \mathrm{~m} / \mathrm{s}$ \\
\hline The short-circuit current at the reference conditions, $I_{\mathrm{sc}, \text { ref }}$ & $\begin{array}{c}N_{s} \times 3.45 \mathrm{~A} \\
\text { (for total array) }\end{array}$ & $\begin{array}{c}N_{s} \times 3.45 \mathrm{~A} \\
\text { (for total array) }\end{array}$ \\
\hline The open-circuit voltage at the reference conditions, $V_{\text {oc,ref }}$ & $\begin{array}{c}N_{m} \times 21.7 \mathrm{~V} \\
\text { (for total array) }\end{array}$ & $\begin{array}{c}N_{m} \times 21.7 \mathrm{~V} \\
\text { (for total array) }\end{array}$ \\
\hline Maximum power point current at the reference conditions, $I_{\mathrm{mp}, \mathrm{ref}}$ & $\begin{array}{c}N_{s} \times 3.15 \mathrm{~A} \\
\text { (for total array) }\end{array}$ & $\begin{array}{c}N_{s} \times 3.15 \mathrm{~A} \\
(\text { for total array) }\end{array}$ \\
\hline Maximum power point voltage at the reference conditions, $V_{\mathrm{mp}, \mathrm{ref}}$ & $\begin{array}{c}N_{m} \times 17.4 \mathrm{~V} \\
\text { (for total array) }\end{array}$ & $\begin{array}{c}N_{m} \times 17.4 \mathrm{~V} \\
\text { (for total array) }\end{array}$ \\
\hline The electrical efficiency at the reference conditions, $\eta_{\mathrm{el}, \mathrm{ref}}$ & 0.12 & 0.12 \\
\hline The current temperature coefficient, $\alpha$ & $1.2 \mathrm{~mA} /{ }^{\circ} \mathrm{C}$ & $1.2 \mathrm{~mA} /{ }^{\circ} \mathrm{C}$ \\
\hline The voltage temperature coefficient, $\beta$ & $-0.077 \mathrm{~V} /{ }^{\circ} \mathrm{C}$ & $-0.077 \mathrm{~V} /{ }^{\circ} \mathrm{C}$ \\
\hline The efficiency correction coefficient for temperature, $\gamma_{\text {ref }}$ & $0.004^{\circ} \mathrm{C}^{-1}$ & $0.004^{\circ} \mathrm{C}^{-1}$ \\
\hline The semiconductor band gap energy, $\varepsilon$ & $1.12 \mathrm{eV}$ & $1.12 \mathrm{eV}$ \\
\hline The effective product of transmittance-absorptance, $(\tau \alpha)$ & 0.9 & 0.9 \\
\hline The PV array emissivity, $\varepsilon_{g}$ & 0.88 & 0.88 \\
\hline The length of solar module, $L_{1}$ & $1.293 \mathrm{~m}$ & $1.293 \mathrm{~m}$ \\
\hline The width of solar module, $L_{2}$ & $0.329 \mathrm{~m}$ & $0.329 \mathrm{~m}$ \\
\hline Time interval, $\Delta t$ & 900 seconds & 3600 seconds \\
\hline
\end{tabular}

The simulated values of open-circuit voltage, maximum power point voltage, short-circuit current, maximum power point current, and the corresponding experimentally measured data during the test day are shown in Figure 4. It can be observed from this figure that there is a good agreement between the experimental and simulated values of these parameters. Further, the root mean square percentage deviations of these parameters are $2.4 \%, 2.28 \%, 4.6 \%$, and $2.98 \%$, respectively.

The simulated and experimental values of energy efficiency, exergy efficiency, and electrical efficiency during the test day are shown in Figure 5. The respective values of root mean square percent deviation are $5.88 \%, 3.49 \%$, and $3.58 \%$, respectively. It can be seen from Figure 5 that there is a good agreement between the simulated and experimental values of the above-mentioned efficiencies.

The good agreement between experiment and simulation values shown in the previous figures demonstrates that the choice of a wind speed of $0.5 \mathrm{~m} / \mathrm{s}$ during our calculations is reasonable (Figures 3-5).
The simulated parameters errors compared with those obtained by the experimental measurement are explained as follows.

(i) The temperature coefficients of current and voltage are assumed constant. In practical cases, they have slight fluctuation due to the solar radiation intensity and $\mathrm{PV}$ array temperature variations.

(ii) The experimental measurements have been obtained from the figures of [35] by interpolation and curve fitting methods. This subject decreases the precision of measured data.

(iii) Wind speed is not constant and has a direct effect on the overall heat loss coefficient that can decrease the precision of calculated overall heat loss coefficient in the computer simulation.

(iv) The effective product of transmittance-absorptance is assumed constant while it is changing during the day with the change of solar incidence angle on PV array surface. 


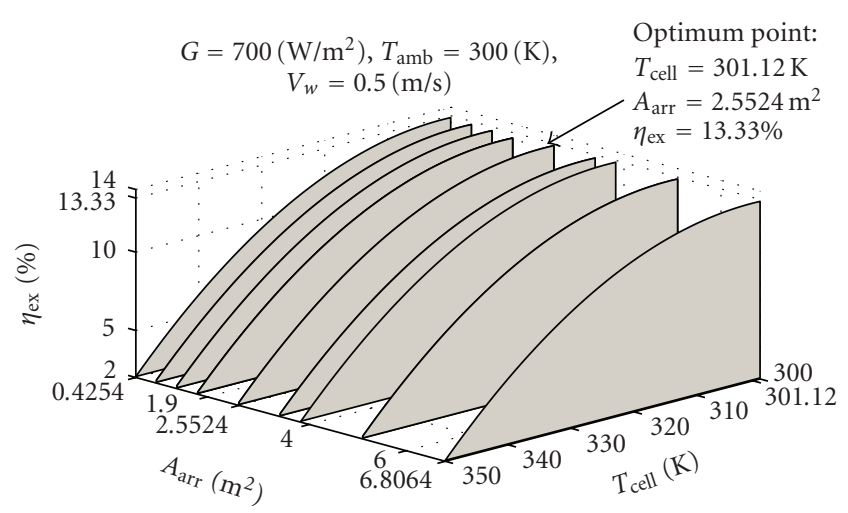

FIGURE 6: The variations of the exergy efficiency as a function of the PV array temperature and the PV array area.

5.2. Optimization Results. The type of PV array, its selected environmental, design conditions, and constant parameters during the optimization procedure are described in Table 1. For the fixed values in Table 1, the optimization procedure gives the following optimized values of the objective function, the independent and dependent optimization parameters:

$\eta_{\mathrm{ex}}=13.33 \%, T_{\text {cell }}=301.12 \mathrm{~K}, A_{\text {arr }}=2.55 \mathrm{~m}^{2}, \eta_{\mathrm{en}}=$ $17.04 \%, \eta_{\mathrm{el}}=11.88 \%, \mathrm{FF}=0.69, I_{\mathrm{sc}}=4.83 \mathrm{~A}, V_{\mathrm{oc}}=$ $62.95 \mathrm{~V}, I_{\mathrm{mp}}=4.38 \mathrm{~A}, V_{\mathrm{mp}}=48.42 \mathrm{~V}, I_{o}=2.12 \times 10^{-6} \mathrm{~A}$, $I_{L}=4.83 \mathrm{~A}, R_{\mathrm{sh}}=687.9 \Omega, R_{s}=0.31 \Omega, C_{p}=0.71 \mathrm{~J} / \mathrm{g} \cdot \mathrm{K}$, $U_{L}=9.56 \mathrm{~W} / \mathrm{m}^{2} \cdot \mathrm{K}, S=1.78 \times 10^{3} \mathrm{~W}, a=4.33 \mathrm{eV}, N_{s}=2$, $N_{m}=3, N_{c}=72$.

5.3. Parametric Studies. The values of climatic, operating, and design parameters in the parametric studies of PV array are described in Table 1, except that the parameters are changed during parametric studies that are indicated by the above of respective figures.

Figure 6 shows the behavior of the exergy efficiency as a function of the PV array temperature $\left(T_{\text {cell }}\right)$ and the $\mathrm{PV}$ array area $\left(A_{\text {arr }}\right)$; it is presented to a range of operational and design conditions where the exergy efficiency takes a global maximum value. The incremented quantities are the PV array area from 0.4254 to $6.8064 \mathrm{~m}^{2}$ and the PV array temperature from 300 to $350 \mathrm{~K}$. It is observed from this figure that there is a global maximum point and the coordinate of this point shows the values of optimized parameters. The calculated values of global maximum point are $T_{\text {cell,opt }}=$ $301.12 \mathrm{~K}, A_{\text {arr,opt }}=2.5524 \mathrm{~m}^{2}$, and $\eta_{\text {ex, } \max }=13.33 \%$. According to this figure, the exergy efficiency has a slight variations $(\sim 13.3 \%)$ with respect to the $\mathrm{PV}$ array area changes $\left(0.4254 \leq A_{\text {arr }} \leq 6.8064 \mathrm{~m}^{2}\right)$ in optimum value of the PV array temperature $\left(T_{\text {cell,opt }}=301.12 \mathrm{~K}\right)$. However, there is an optimized point for the PV array area that is equal with $A_{\text {arr,opt }}=2.5524 \mathrm{~m}^{2}$. On the other hand, by increasing the PV array temperature, the exergy efficiency is constant initially and then decreases quickly from $\sim 13.3 \%$ to $\sim 2 \%$ after the PV array temperature reaches about $302 \mathrm{~K}$. This indicated the optimum range of the PV array temperature $\left(T_{\mathrm{amb}} \leq T_{\text {cell }} \leq 302 \mathrm{~K}\right)$ for given climatic and design parameters (Table 1 ).

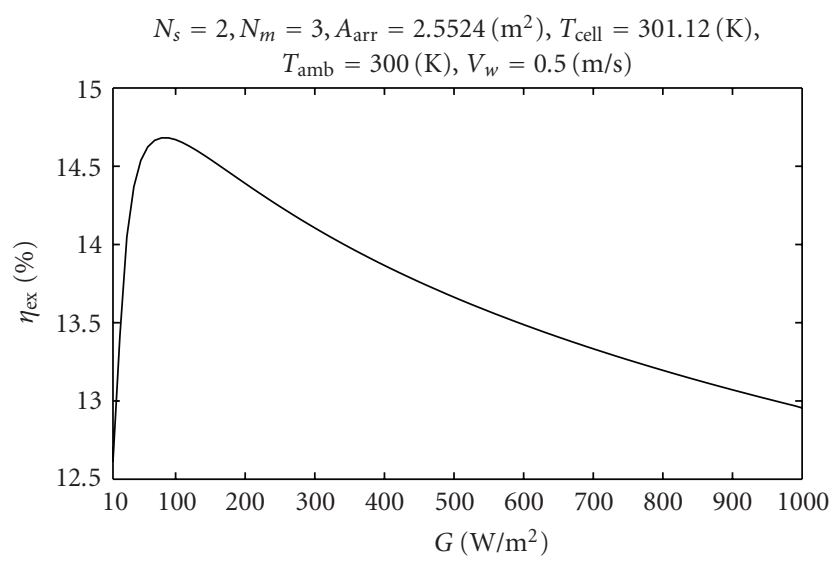

FIGURE 7: The variations of the exergy efficiency with respect to the solar radiation intensity.

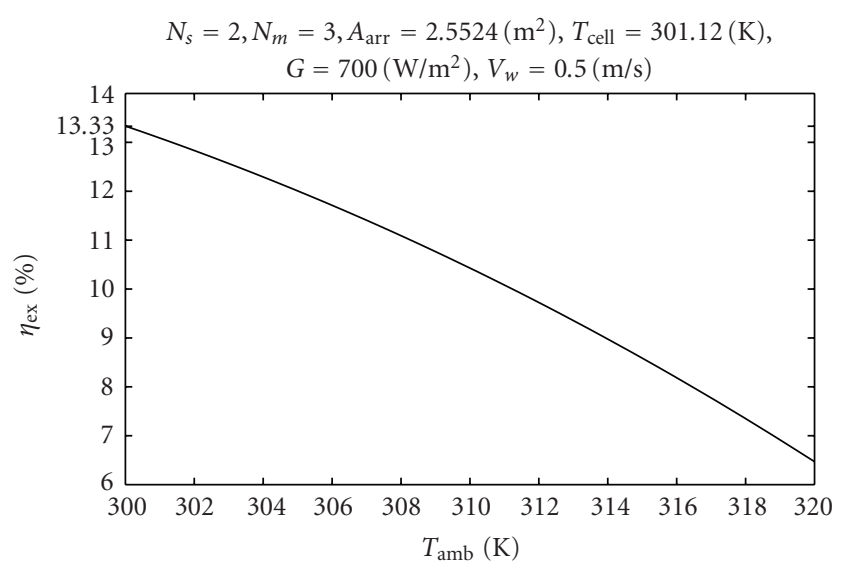

Figure 8: The effect of ambient temperature on the exergy efficiency.

In order to have maximum exergy efficiency, PV array temperature should be kept near the ambient temperature, or in other words, PV array temperature should be controlled. In order to control PV array temperature, there are some practical methods such as spraying water on the top surface of photovoltaic modules [15] or combining of PV modules in photovoltaic/thermal (PV/T) collectors [16].

Figure 7 shows the variations of exergy efficiency with respect to solar radiation intensity. It is observed that the exergy efficiency increases from $\sim 12.61 \%$ to $\sim 14.68 \%$ initially, and then after attaining the solar radiation intensity of about $G \approx 80 \mathrm{Wm}^{2}$, it decreases to $\sim 12.95 \%$. This indicates the optimum value of solar radiation intensity for given climatic and design parameters (Table 1). Since this parameter varies during the day, the design of PV array should be based on the daily or monthly average of this parameter.

Figure 8 shows the effect of ambient temperature on the exergy efficiency. Increasing the ambient temperature from 300 to $320 \mathrm{~K}$ determines the sensible decrease of exergy efficiency from $\sim 13.33 \%$ to $\sim 6.5 \%$. Since the ambient temperature changes during the day, PV array design should be based on the daily average of this parameter. 
The average value of a function $f(t)$ on a time interval $[0, M]$ is defined as follows [36]:

$$
\bar{f}=\frac{1}{M} \int_{0}^{M} f(t) d t=\frac{\sum_{0}^{M} f(\mathrm{t})}{M},
$$

where $M$ is time in hour.

\section{Conclusion}

On the basis of theoretical results obtained in the present paper, the following conclusions have been drawn.

(i) The electrical and exergetic models of PV array presented in this study are in good agreement with the experimental results of Barker and Norton [35] (Figures 3-5).

(ii) The PV array temperature has a great effect on the exergy efficiency. The exergy efficiency of a PV array can be improved if the heat can be removed from the PV array surface. In order to remove heat from the PV array surface, there are some practical methods such as spraying water on the top surface of photovoltaic modules [15] or combining of PV modules in photovoltaic/thermal (PV/T) collectors [16] (Figure 6).

(iii) Increasing the solar radiation intensity, the exergy efficiency of PV array increases initially and then decreases after attaining the solar radiation intensity of about a maximum point (Figure 7).

(iv) While the ambient temperature is increasing, the exergy efficiency of PV array decreases (Figure 8).

(v) The design parameters such as PV array area have a little effect on the exergy efficiency (Figure 6).

\section{Nomenclature}

$\begin{array}{ll}a: & \text { Ideality factor }(\mathrm{eV}) \\ A: & \text { Area }\left(\mathrm{m}^{2}\right) \\ \mathrm{C}_{p}: & \text { Heat capacity of the silicon material }(\mathrm{J} / \mathrm{g} \cdot \mathrm{K}) \\ \mathrm{CIGS}: & \text { Copper Indium Gallium Selenide } \\ E: & \text { Electrical power }(\mathrm{W}) \\ \mathrm{EPBT}: & \text { Energy Payback Time } \\ \mathrm{Ex}: & \text { Exergy }(\mathrm{W}) \\ \mathrm{FF}: & \text { Fill Factor } \\ G: & \text { Solar radiation intensity }\left(\mathrm{W} / \mathrm{m}^{2}\right) \\ h: & \text { Heat transfer coefficient }\left(\mathrm{W} / \mathrm{m}^{2} \cdot \mathrm{K}\right) \\ I: & \text { Circuit current }(\mathrm{A}) \\ I_{\mathrm{c} \cdot \mathrm{v}}: & \text { Irreversibility in control volume }(\mathrm{J}) \\ I-V: & \text { Current-voltage } \\ L: & \text { Dimensions of solar module }(\mathrm{m}) \\ m: & \text { PV array mass }(\mathrm{g}) \\ M: & \text { Time }(\mathrm{hr}) \\ n: & \text { Number of parameters } \\ N_{c}: & \text { Number of cells in PV module } \\ N_{m}: & \text { Number of modules in series per string } \\ N_{s}: & \text { Number of string }\end{array}$

NOCT: Nominal operating Cell Temperature conditions

PV: Photovoltaic

PV/T: Photovoltaic/thermal collector

$R: \quad$ Resistance $(\Omega)$

RMS: $\quad$ Root Mean Square percentage deviation (\%)

$S: \quad$ Solar absorbed flux (W)

SQP: Sequential Quadratic Programming

SRC: Standard Rated Conditions

$t: \quad$ Time interval (second)

$T: \quad$ Temperature $(\mathrm{K})$

$\mathrm{U}_{L}$ : Overall heat loss coefficient from the PV array to the environment $\left(\mathrm{W} / \mathrm{m}^{2} \cdot \mathrm{K}\right)$

$V: \quad$ Circuit voltage $(V)$, wind speed $(\mathrm{m} / \mathrm{s})$

$\mathrm{X}$ : Experimental or simulated value of parameter.

\section{Greek Symbols}

$\alpha: \quad$ Current temperature coefficient $\left(\mathrm{mA} /{ }^{\circ} \mathrm{C}\right)$

$\beta$ : $\quad$ Voltage temperature coefficient $\left(V /{ }^{\circ} \mathrm{C}\right)$

$\gamma: \quad$ Efficiency correction coefficient for temperature $\left(\mathrm{o}^{-1}\right)$

$\Delta:$ Difference in current, temperature, time, voltage

$\varepsilon: \quad$ Global emissivity, semiconductor band gap energy $(\mathrm{eV})$

$\eta: \quad$ Efficiency (\%)

$\sigma: \quad$ Stefan-Boltzmann's constant $\left(\mathrm{W} / \mathrm{m}^{2} \mathrm{~K}^{4}\right)$

$(\tau \alpha)$ : The effective product of transmittance-absorptance.

\section{Subscripts}

1: $\quad$ Length

2: $\quad$ Width

arr: Array

amb: Ambient

cell: Cell, array

conv: Convection

des: Destroyed

D: $\quad$ Diode

el: $\quad$ Electrical

en: Energy

ex: Exergy

exp: Experimental

g: $\quad$ Glass

GH: The highest energy content of the electron

$i$ I $\quad$ Ith parameter

in: Inlet

$L: \quad$ The available energy content of the electron, light current

los: Loss

max: Maximum

mod: Module

mp: $\quad$ Maximum power point

new: New

NOCT: At NOCT conditions

$o: \quad$ Reverse saturation

oc: Open-circuit 
opt: Optical, optimum

out: Outlet

rad: Radiative

ref: Reference

$s$ : Series

sc: Short-circuit

sh: Shunt

sim: Simulated

sky: Sky

sun: Sun

$w$ : Wind.

\section{Acknowledgments}

The authors acknowledge Professor. A. D. Sahin [3] for responding then inquiries and acknowledge the constructive comments of Dr. M. Abdolzadeh [15].

\section{References}

[1] R. Petela, "An approach to the exergy analysis of photosynthesis," Solar Energy, vol. 82, no. 4, pp. 311-328, 2008.

[2] R. Petela, "Exergy of undiluted thermal radiation," Solar Energy, vol. 74, no. 6, pp. 469-488, 2003.

[3] A. D. Sahin, I. Dincer, and M. A. Rosen, "Thermodynamic analysis of solar photovoltaic cell systems," Solar Energy Materials and Solar Cells, vol. 91, no. 2-3, pp. 153-159, 2007.

[4] R. T. Ross and T.-L. Hsiao, "Limits on the yield of photochemical solar energy conversion," Journal of Applied Physics, vol. 48, no. 11, pp. 4783-4785, 1977.

[5] P. T. Landsberg and T. Markvart, "The carnot factor in solarcell theory," Solid-State Electronics, vol. 42, no. 4, pp. 657-659, 1998.

[6] T. Markvart and P. T. Landsberg, "Thermodynamics and reciprocity of solar energy conversion," Physica E, vol. 14, no. 1-2, pp. 71-77, 2002.

[7] P. Würfel, "Thermodynamic limitations to solar energy conversion," Physica E, vol. 14, no. 1-2, pp. 18-26, 2002.

[8] G. P. Smestad, "Conversion of heat and light simultaneously using a vacuum photodiode and the thermionic and photoelectric effects," Solar Energy Materials and Solar Cells, vol. 82, no. 1-2, pp. 227-240, 2004.

[9] J. Bisquert, D. Cahen, G. Hodes, S. Ruhle, and A. Zaban, "Physical chemical principles of photovoltaic conversion with nanoparticulate, mesoporous dye-sensitized solar cells," Journal of Physical Chemistry B, vol. 108, no. 24, pp. 8106-8118, 2004.

[10] X. Gong and M. Kulkarni, "Design optimization of a large scale rooftop photovoltaic system," Solar Energy, vol. 78, no. 3, pp. 362-374, 2005.

[11] G. Černivec, J. Krč, F. Smole, and M. Topič, "Band-gap engineering in CIGS solar cells using Nelder-Mead simplex optimization algorithm," Thin Solid Films, vol. 511-512, pp. 60-65, 2006.

[12] A. A. Ghoneim, "Design optimization of photovoltaic powered water pumping systems," Energy Conversion and Management, vol. 47, no. 11-12, pp. 1449-1463, 2006.

[13] V. Badescu, "Simple optimization procedure for silicon-based solar cell interconnection in a series-parallel PV module," Energy Conversion and Management, vol. 47, no. 9-10, pp. 1146-1158, 2006.
[14] E. Skoplaki, A. G. Boudouvis, and J. A. Palyvos, "A simple correlation for the operating temperature of photovoltaic modules of arbitrary mounting," Solar Energy Materials and Solar Cells, vol. 92, no. 11, pp. 1393-1402, 2008.

[15] M. Abdolzadeh and M. Ameri, "Improving the effectiveness of a photovoltaic water pumping system by spraying water over the front of photovoltaic cells," Renewable Energy, vol. 34, no. 1, pp. 91-96, 2009.

[16] A. S. Joshi, A. Tiwari, G. N. Tiwari, I. Dincer, and B. V. Reddy, "Performance evaluation of a hybrid photovoltaic thermal (PV/T) (glass-to-glass) system," International Journal of Thermal Sciences, vol. 48, no. 1, pp. 154-164, 2009.

[17] A. S. Joshi, I. Dincer, and B. V. Reddy, "Thermodynamic assessment of photovoltaic systems," Solar Energy, vol. 83, no. 8, pp. 1139-1149, 2009.

[18] F. Sarhaddi, S. Farahat, H. Ajam, and F. Sobhnamayan, "Thermodynamic optimization of solar parabolic cookers and comparison with energy analysis," in Proceedings of the 5th International Chemical Engineering Congress (IChEC '08), Kish Island, Iran, 2008.

[19] S. Farahat, F. Sarhaddi, and H. Ajam, "Exergetic optimization of flat plate solar collectors," Renewable Energy, vol. 34, no. 4, pp. 1169-1174, 2009.

[20] H. Ajam, S. Farahat, and F. Sarhaddi, "Exergetic optimization of solar air heaters and comparison with energy analysis," International Journal of Thermodynamics, vol. 8, no. 4, pp. 183-190, 2005.

[21] W. De Soto, Improvement and validation of a model for photovoltaic array performance, M.S. thesis, Solar Energy Laboratory, University of Wisconsin-Madison, Madison, Wis, USA, 2004.

[22] Siemens Company, "Siemens solar module SM55," 2009, http://www.elk.itu.edu.tr/ gunes/sm55.pdf.

[23] A. Luque and S. Hegedus, Handbook of Photovoltaic Science and Engineering, John Wiley \& Sons, Chichester, UK, 2003.

[24] J. H. Watmuff, W. W. S. Charters, and D. Proctor, "Solar and wind induced external coefficients for solar collectors," COMPLES, no. 2, p. 56, 1977.

[25] S. P. Sukhatme, Solar Energy, McGraw-Hill, New York, NY, USA, 1993.

[26] T. J. Kotas, The Exergy Method of Thermal Plant Analysis, Krieger, Malabar, Fla, USA, 1995.

[27] K. F. V. Wong, Thermodynamics for Engineers, University of Miami, CRC Press LLC, Boca Raton, Fla, USA, 2000.

[28] A. Bejan, Advanced Engineering Thermodynamics, John Wiley \& Sons, Chichester, UK, 1998.

[29] M. Feidt, Thermodynamique et Optimisation Energétique des Systèmes et Procédés, Tech \& Doc, Paris, France, 1996.

[30] A. Bejan, Entropy Generation through Heat and Fluid Flow, John Wiley \& Sons, Chichester, UK, 1982.

[31] K. Altfeld, W. Leiner, and M. Fiebig, "Second law optimization of flat-plate solar air heaters-part I: the concept of net exergy flow and the modeling of solar air heaters," Solar Energy, vol. 41, no. 2, pp. 127-132, 1988.

[32] K. Altfeld, W. Leiner, and M. Fiebig, "Second law optimization of flat-plate solar air heaters-part 2: results of optimization and analysis of sensibility to variations of operating conditions," Solar Energy, vol. 41, no. 4, pp. 309-317, 1988.

[33] A. R. Regel and V. M. Glazov, Physical Properties of Electronic Melts, Nauka, Moscow, UK, 1980.

[34] The MathWorks Inc., “Optimization toolbox user's guide version 2," 2009, http://www.mathworks.com/. 
[35] G. Barker and P. Norton, "Building America system performance test practices: part 1-photovoltaic systems," Tech. Rep. NREL/TP-550-30301, National Renewable Energy Laboratory (NREL), Golden, Colo, USA, 2003, http://www .nrel.gov/docs/fy03osti/30301.pdf.

[36] G. H. Hardy, J. E. Littlewood, and G. Pólya, Inequalities, Cambridge University Press, Cambridge, UK, 2nd edition, 1988. 

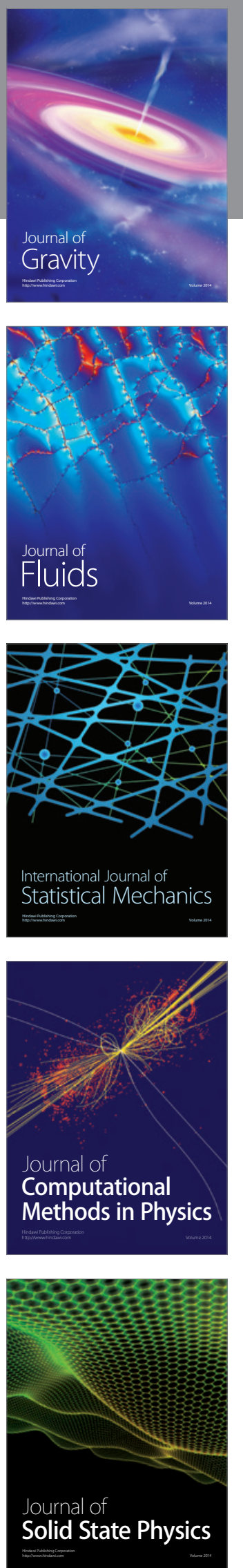

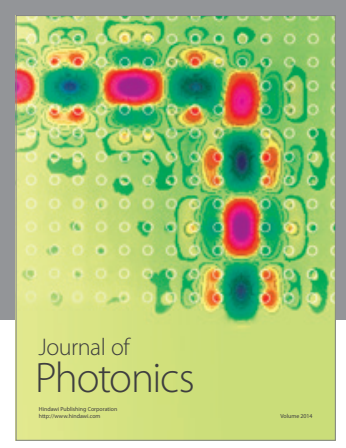

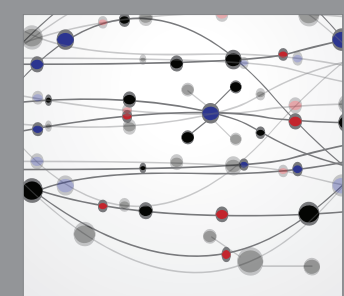

The Scientific World Journal
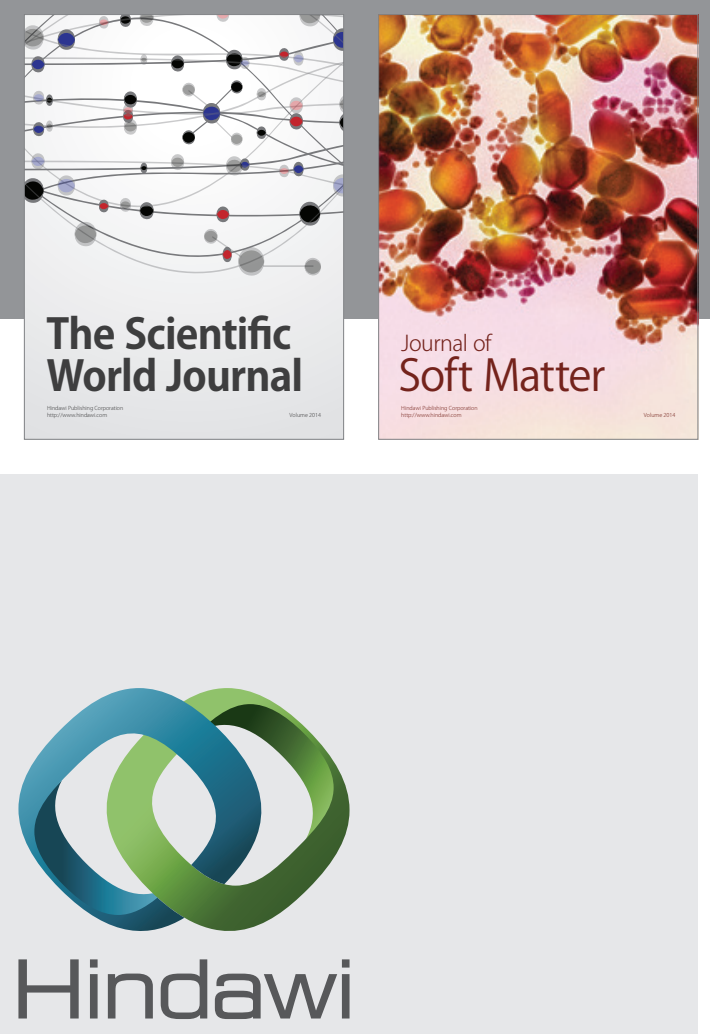

Submit your manuscripts at

http://www.hindawi.com
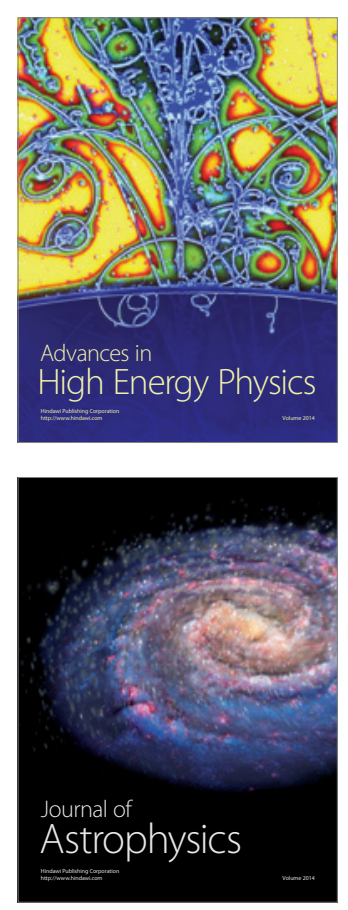
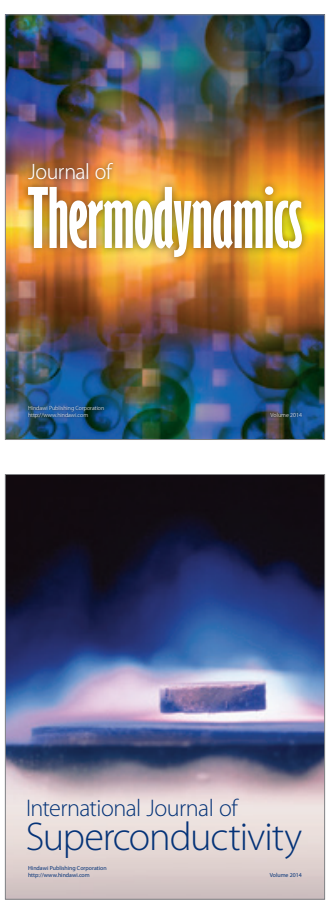
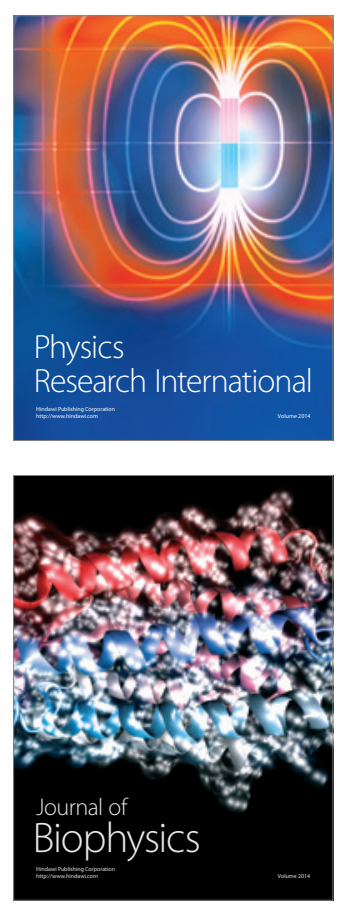
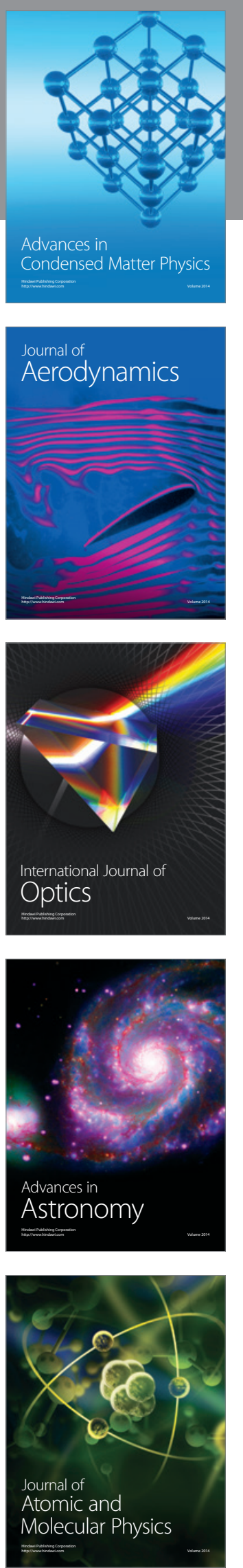